\title{
Nutritional interactions in Galapagos Rift hydrothermal vent communities: inferences from stable carbon and nitrogen isotope analyses
}

\author{
Charles R. Fisher ${ }^{1}$, James J. Childress ${ }^{2}$, Stephen A. Macko ${ }^{3}$, James M. Brooks ${ }^{4}$ \\ ${ }^{1}$ Department of Biology, 208 Mueller Laboratory, Pennsylvania State University, University Park, Pennsylvania 16802, USA \\ ${ }^{2}$ Department of Biological Sciences and the Marine Science Institute, University of California, Santa Barbara, \\ California 98106, USA \\ ${ }^{3}$ Department of Environmental Sciences, University of Virginia, Charlottesville, Virginia 22903, USA \\ ${ }^{4}$ Geochemical and Environmental Research Group, Department of Oceanography, Texas A \& M University, College Station, \\ Texas 77845, USA
}

\begin{abstract}
Nutritional interactions among invertebrates at 3 vent sites on the Galapagos Rift are examined through the use of stable carbon and nitrogen isotopes. A large number of individuals of several vent species were analyzed and this provides previously unavailable insights into the variability within various groups. Stable nitrogen isotope contents $\left(\delta^{15} \mathrm{~N}\right.$ values) of vent invertebrates are below $11 \%$. This is significantly lower than all non-vent deep-sea fauna examined to date, which makes $\delta^{15} \mathrm{~N}$ values an excellent tool in identifying vent-dependent fauna. However, the large range in $\delta^{15} \mathrm{~N}$ values among both primary producers and many vent consumer species renders it of limited use in determining either the trophic level of most individual species or the total number of trophic levels in vent communities. Stable carbon isotope content $\left(\delta^{13} \mathrm{C}\right.$ values) in vent invertebrates from the Galapagos Rift range from -9 to $-37 \%$, which encompasses the range of non-vent deep-sea fauna $(-17$ to $-22 \%)$ and extends significantly beyond it. Many vent invertebrates have $\delta^{13} \mathrm{C}$ values which overlap that of ambient deep-sea fauna, however in several cases the extreme values can be linked to specific endogenous vent sources. When both nitrogen and carbon are taken together, robust trophic links can be established between several vent taxa, and considerable nutritional plasticity in other taxa becomes evident.
\end{abstract}

KEY WORDS: Hydrothermal vent - Food web - Stable isotopes - Chemoautotrophy

\section{INTRODUCTION}

One of the original indications that the carbon and nitrogen sources for hydrothermal vent fauna were of local origin was the recognition that the stable carbon and nitrogen values for several vent organisms were significantly different than those of other deep-sea fauna (Rau \& Hedges 1979, Rau 1981a, b). The primary producers at the base of the food chain in hydrothermal vent environments are chemoautotrophic bacteria, some of the most abundant of which are endosymbiotic in several of the dominant sessile invertebrate animals (Jannasch 1989, Fisher 1990). As a result of chemoautotrophic carbon fixation and assimilation of inorganic nitrogen sources by these bacteria, much of the vent fauna have lower $\delta^{15} \mathrm{~N}$ values and either lower or higher $\delta^{13} \mathrm{C}$ values than other deep-sea fauna (see Kennicutt et al. 1992 for review).

At the Galapagos Rift hydrothermal vent sites the sessile fauna is dominated by 3 species of symbiontcontaining invertebrates: Riftia pachyptila, a vestimentiferan tube-worm; Calyptogena magnifica, a vesicomyid bivalve; and Bathymodiolus thermophilus, a mytilid bivalve (Hessler \& Smithey 1983, Hessler et al. 1988). These 3 species are primary producers at this site, their autotrophic symbionts being functionally analogous to the chloroplasts of green plants (Cavanaugh 1985, Fisher 1990). The stable carbon and nitrogen isotope values of each of these species are distinct from 'normal' deep-sea marine organic carbon 
and nitrogen values. Stable carbon values for tissue from non-vent marine organisms without chemoautotrophic symbionts normally range from -24 to $-12 \%$ and values from -22 to $-17 \%$ have been reported for non-vent deep-sea fauna (Brooks et al. 1987, Van Dover \& Fry 1989). $\delta^{15} \mathrm{~N}$ values for marine biological material normally range from about -2 to $20 \%$ the lower values are associated with nitrogen-fixing plankton) (see Owens 1987 for review), and values from 11 to $16 \%$ have been reported for non-vent deepsea fauna (Brooks et al. 1987, Van Dover \& Fry 1989). Stable nitrogen isotope values for all 3 of the symbiontcontaining invertebrates from the Galapagos Rift vents are at or below the low end of the range for oceanic organic nitrogen and well below values reported for other deep-sea fauna. The stable carbon values for these organisms are also unique; the bivalves are significantly more negative than normal marine fauna and the vent vestimentiferans are more positive than other deep-sea faund (Rau 1985, Fisher et al. $1988 \mathrm{a}, \mathrm{b}, \mathrm{c})$

Other primary producers in the vent communities are free-living chemoautotrophic or methanotrophic bacteria. Microbiological studies indicate that these bacteria abound both in the water column and attached to surfaces in the vent field (Jannasch 1984). No direct measures of the stable isotopic values of these bacteria have been made at the Galapagos Rift vents. Previous studies at other sites have suggested that there are significant pools of relatively heavy organic carbon (about 12\%) in free-living vent bacterial populations, based on measurements of $\delta^{13} \mathrm{C}$ values in primary consumers (Van Dover et al. 1988, Van Dover \& Fry 1989). As pointed out by the authors, this argument is consistent with $\delta^{13} \mathrm{C}$ values reported from some non-vent bacterial mat communities (Calder \& Parker 1973, Schiklowski et al. 1984). Recent determinations of $\delta^{15} \mathrm{~N}$ and $\delta^{13} \mathrm{C}$ values for bacterial mat material at other vent sites ranged from -9.6 to $1.6 \%$ and -41.6 to $-16.8 \%$ respectively (Van Dover \& Fry 1993).

Here we examine the nutritional relations among a range of vent invertebrates using a relatively large number of stable isotope values, in situ observations, and what is known of their feeding biology from other investigations and observations.

\section{MATERIALS AND METHODS}

Animal collection. Animals were collected from 3 vent sites (Rose Garden, Mussel Bed, and New Vent) on the Galapagos Rift $\left(00^{\circ} 48.25^{\prime} \mathrm{N}, 86^{\circ} 13.48^{\prime} \mathrm{W}\right)$ in 1988 (Hessler et al. 1985, 1988) by the submersible 'Alvin'. The animals were held in a temperature- insulated box during recovery of the submersible, and transferred to chilled (ca $10^{\circ} \mathrm{C}$ ) seawater on board ship. Pieces of soft tissue (gonads and viscera were avoided) were removed from the larger specimens and frozen in liquid nitrogen within a few hours of recovery of the submersible. Smaller animals were often frozen whole. Five of the crab samples (Bythograea thermydron) were removed from specimens which had been fixed in formaldehyde and stored for about 1 yr. There was no apparent difference between the stable isotopic contents of the fixed and frozen crabs, which is consistent with previous observations of minimal isotopic effects of such treatment $(<1 \%$; Rau et al. 1982).

Collection of water samples. Water samples were collected by 'Alvin' using the 'Scanner' (courtesy of K. Johnson, Monterey Bay Aquarium Research Institute and Moss Landing Marine Laboratory). The intake tube for this sampling device is positioned by the submersible and a temperature probe adjacent to the intake records the temperature of the sample as it is collected. After recovery, the water samples were frozen for later analysis of $8^{13} \mathrm{C}$ of total inorganic carbon.

Stable isotope analyses. The tissue stable isotope determinations were conducted on freeze-dried and acidified samples. Carbon isotope analyses were conducted by standard methods using both Craig-type and closed-vessel combustion techniques (Sackett et al. 1970, Schoell et al. 1983, Macko et al. 1987). Carbon dioxide from the combusted tissue or acidified water samples was analyzed on either a Finnigan MAT-251 isotope ratio mass spectrometer or a V. G. Micromass 'Prism' mass spectrometer and is reported relative to PDB (PeeDee Belemnite). The stable nitrogen determinations were accomplished on a V. G. Micromass 'Prism' mass spectrometer and reported relative to atmospheric molecular nitrogen.

Ribulose-1,5-biphosphate (RuBP) carboxylase determinations and TEM observations. Pieces of gill tissue from both the turrid gastropod Phymorrhynchus $\mathrm{sp}$. and the limpet Neomphalus fretterae were fixed on board ship in glutaraldehydo and later processed for examination by transmission electron microscopy (TEM) using standard techniques routinely used on other vent molluscs (Fisher et al. 1987). Additional pieces of gill from 2 individuals of each of these species, and both tissue samples and whole specimens of the commensal polychaete Branchipolynoe symmytilida, were assayed for RuBP carboxylase activity using a modification of the ${ }^{14} \mathrm{C}$ incorporation method of Wishnick \& Lane (1971). Trophosome tissue from Riftia pachyptila and gills from chemoautotrophic symbiontcontaining mussels were run at the same time and served as positive controls 
Table $1 . \delta^{13} \mathrm{C}$ of total inorganic carbon $\left(\Sigma \mathrm{CO}_{2}\right)$ in vent water

\begin{tabular}{|lcccc|}
\hline Dive no. & Site & Area & Water temperature & $\delta^{13} \mathrm{C}(\%)$ \\
\hline 2026 & Mussel Bed & 'Smokey pit' & $\mathrm{ca} 8-9^{\circ} \mathrm{C}$ & +0.4 \\
2027 & Rose Garden & Central Riftia pachyptila clump & $16^{\circ} \mathrm{C}$ & -1.6 \\
2029 & New Vent & Among Riftia pachyptila & 'Shimmering $\mathrm{H}_{2} \mathrm{O}\left(10-20^{\circ} \mathrm{C}\right)^{\text {ส }}$ & -0.4 \\
2031 & Rose Garden & Near field & Ambient $\left(\mathrm{ca} 1.8^{\circ} \mathrm{C}\right)$ & -0.5 \\
a 'Alvin' temperature probe inoperable during dive but other measurements suggest temperatures within this range
\end{tabular}

Table $2.8^{13} \mathrm{C}$ and $\delta^{15} \mathrm{~N}$ values of dominant invertebrates with chemoautotrophic symbionts

\begin{tabular}{|c|c|c|c|c|c|c|c|c|c|c|}
\hline \multirow[t]{2}{*}{ Species } & \multicolumn{5}{|c|}{$\delta^{13} \mathrm{C}$} & \multicolumn{5}{|c|}{$-\delta^{15} \mathrm{~N}$} \\
\hline & Min. & Max. & Mean & $\mathrm{n}$ & $\mathrm{SD}$ & Min. & Max. & Mean & $\mathrm{n}$ & $\mathrm{SD}$ \\
\hline $\begin{array}{l}\text { Riftia pachyptila } \\
\text { (trophosome and vestimentum) }\end{array}$ & -13.4 & -9.7 & -11.6 & 29 & 0.99 & -2.91 & 5.04 & 1.95 & 25 & 1.87 \\
\hline $\begin{array}{l}\text { Calyptogena magnifica } \\
\text { (gill) }\end{array}$ & -34.9 & -32 & -33.4 & 42 & 0.73 & -0.86 & 4.47 & 1.44 & 29 & 1.45 \\
\hline $\begin{array}{l}\text { Bathymodiolus thermophilusc } \\
\text { (gill) }\end{array}$ & -37.3 & -32 & -35.4 & 66 & 1.38 & -8.08 & 9.64 & 2.66 & 52 & 5.01 \\
\hline \multicolumn{11}{|c|}{$\begin{array}{l}{ }^{2} \text { Trophosome and/or vestimentum tissue was assayed from } 16 \text { individuals for } \delta^{13} \mathrm{C} \text { and } 15 \text { individuals for } \delta^{15} \mathrm{~N} \text {. There was no } \\
\text { consistent relation between the stable isotopic content of trophosome and vestimentum tissue }\end{array}$} \\
\hline \multicolumn{11}{|c|}{$\begin{array}{l}{ }^{b} \text { In } 1985 \mathrm{C} \text {. magnifica gill tissue } \delta^{13} \mathrm{C} \text { and } \delta^{15} \mathrm{~N} \text { were on the average } 0.6 \% \text { and } 2.7 \% \text { less than the non-gill tissue respectively } \\
\text { (Fisher et al. 1988b) }\end{array}$} \\
\hline \multicolumn{11}{|c|}{$\begin{array}{l}\text { 'In } 1985 B \text {. thermophilus gill tissue } 8^{13} \mathrm{C} \text { was on the average } 1.3 \% \text { less than the non-gill tissue (Fisher et al. 1988c). There was } \\
\text { no consistent relation between gill and non-gill } \delta^{15} \mathrm{~N} \text { values. The wide range in } \delta^{15} \mathrm{~N} \text { in } \mathrm{B} \text {. thermophilus is strongly correlated } \\
\text { with collection site, with the more negative values found in mussels collected from the highest temperature areas (Fisher et } \\
\text { al. 1988c, 1989) }\end{array}$} \\
\hline
\end{tabular}

\section{RESULTS}

The $\delta^{13} \mathrm{C}$ values of the dissolved inorganic carbon were determined in 4 water samples taken from different areas of the vent fields (Table 1). Values in water from the Rose Garden site ranged from $-0.5 \%$ in ambient bottom water $\left(\mathrm{ca} 1.8^{\circ} \mathrm{C}\right.$ ) to $-1.6 \%$ in water collected from among the central clump of Riftia pachyptila, which registered $16^{\circ} \mathrm{C}$ during collection of the sample. The $\delta^{13} \mathrm{C}$ of the inorganic $\mathrm{C}$ in a sample of 'shimmering' water among tube worms from the New Vent site was $-0.4 \%$ (the 'Alvin' temperature probe was inoperable during that dive but other measurements made at New Vent suggest that the water temperature was likely between 10 and $20^{\circ} \mathrm{C}$ ). A sample taken from the 'smokey pit' at Mussel Bed (ca 8 to $9^{\circ} \mathrm{C}$ ) had a $\delta^{13} \mathrm{C}$ of $0.4 \%$. Thus, the range of $\delta^{13} \mathrm{C}$ values of the total inorganic carbon pool in the water to which vent fauna are exposed is about $2 \%$ and is not a significant source of the variation in that fauna (see also Childress et al. 1993).

Tissues from many individuals of the 3 dominant symbiont-containing species were analyzed for stable
$\mathrm{C}$ and $\mathrm{N}$ isotope content in conjunction with related studies of microhabitat variation in the bivalves and tubeworms (C.R.F. unpubl.). That data is presented in summary form in Table 2. There was no apparent variation in isotopic content which was driven primarily by the vent site (data not shown), although significant variations in mussel $\delta^{15} \mathrm{~N}$ values were correlated with the specific microhabitat the animals were collected from within a site (see Fisher et al. 1988a).

The stable carbon and nitrogen contents ( $\delta$ values) were also determined for 20 additional species of animals collected in, or near to, the Galapagos vents. Samples from 79 individuals were analyzed for $\delta^{13} \mathrm{C}$ and samples from 60 individuals were analyzed for $\delta^{15} \mathrm{~N}$ (Table 3). Although these consumers were collected from all 3 vent areas, they are not sorted by site because there were no significant differences in the stable isotope values between sites. In Fig. 1a, a subset of these data is presented which consists of all individuals for which both $\delta^{15} \mathrm{~N}$ and $\delta^{13} \mathrm{C}$ were determined. The 'nonvent' animals were collected from outside of the vent field (not associated with endemic vent species), but within $100 \mathrm{~m}$ of active venting. Like other deep-sea 
Table 3. Stable isotope values of invertebrates collected in and around Galapagos Rift vents

\begin{tabular}{|c|c|c|c|c|c|c|c|c|c|c|}
\hline \multirow[t]{2}{*}{ Species } & \multicolumn{5}{|c|}{$\delta^{13} \mathrm{C}$} & \multirow[b]{2}{*}{ Min. } & \multirow{2}{*}{ Max. } & \multirow{2}{*}{$\begin{array}{l}\delta^{15} \mathrm{~N}- \\
\text { Mean }\end{array}$} & \multirow[b]{2}{*}{$\mathrm{n}$} & \multirow{2}{*}{$\mathrm{SD}$} \\
\hline & Min & Max. & Mean & $\mathrm{n}$ & $\mathrm{SD}$ & & & & & \\
\hline \multicolumn{11}{|l|}{ Non-vent } \\
\hline Holothurians & -19.2 & -19.0 & -19.1 & 2 & & 13.8 & 18.8 & 16.3 & 2 & \\
\hline Isoparactis sp. (large anemone) & & & -19.3 & 1 & & & & 16.0 & 1 & \\
\hline Large pycnogonid & -20.6 & -19.0 & -19.8 & 2 & & & & 14.9 & 1 & \\
\hline \multicolumn{11}{|l|}{ Near field } \\
\hline Isoparactis sp. (small anemone) & -19.4 & -13.9 & -17.6 & 6 & 2.2 & -1.4 & 11.8 & 7.3 & 3 & 7.6 \\
\hline Thermopalia taraxaca & & & & & & & & & & \\
\hline (colonial siphonophore) & & & -29.8 & 1 & & & & & & \\
\hline Serpulid (sp. a) & -20.6 & -18.9 & -19.7 & 2 & & & & & & \\
\hline Serpulid (sp. b) & & & -36.7 & 1 & & & & 9.3 & 1 & \\
\hline Jellyfish & & & -18.7 & 1 & & & & 7.1 & 1 & \\
\hline \multicolumn{11}{|c|}{ Central (among symbiont-containing species) } \\
\hline \multicolumn{11}{|c|}{ Molluscs } \\
\hline \multicolumn{11}{|c|}{ Phymorrhynchus sp. (turrid gastropod) } \\
\hline Foot & -32.6 & -29.6 & -31.0 & 9 & 0.9 & 4.3 & 7.3 & 5.5 & 7 & 1.0 \\
\hline Gill & & & -32.5 & 1 & & & & 3.4 & 1 & \\
\hline Lepetodrilus pustulosis (limpet) & -28.5 & -13.9 & -20.2 & 6 & 5.1 & 5.8 & 8.6 & 6.6 & 5 & 1.1 \\
\hline Euleptopsis vitrea (limpet) & & & -26.4 & 1 & & & & 4.2 & 1 & \\
\hline Neomphalus fretterae (limpet) & -19.0 & -17.5 & -18.2 & 6 & 0.5 & 6.6 & 10.5 & 8.6 & 6 & 1.6 \\
\hline \multicolumn{11}{|l|}{ Crustaceans } \\
\hline Alvinocaris Jusca (shrimp) & -29.3 & -16.3 & -21.7 & 11 & 4.8 & 3.0 & 8.3 & 5.9 & 7 & 2.0 \\
\hline Ventiella sulfuris (amphipod) & -30.0 & -21.9 & -24.1 & 5 & 3.4 & 0.2 & 5.4 & 2.3 & 3 & 2.8 \\
\hline \multicolumn{11}{|l|}{ Bythograea thermydron } \\
\hline (brachyuran crab) & -20.9 & -11.9 & -17.0 & 10 & 2.9 & 7.5 & 10.4 & 8.8 & 7 & 1.0 \\
\hline \multicolumn{11}{|c|}{ Munidopsis subsquamosa (galatheid crab) } \\
\hline Muscle (aduits) & -18.5 & -16.9 & -17.7 & 2 & & & & 7.7 & 1 & \\
\hline Intact leg (juveniles) & -24.4 & -23.0 & -23.7 & 3 & 0.7 & 6.3 & 6.8 & 6.6 & 3 & 0.3 \\
\hline \multicolumn{11}{|l|}{ Others } \\
\hline \multicolumn{11}{|l|}{ Bythites hollisi (fish) } \\
\hline Gill & & & -19.5 & 1 & & & & 11.9 & 1 & \\
\hline Muscle & & & -19.0 & 1 & & & & 8.0 & 1 & \\
\hline Euphrosine rosacea (polychaete) & -30.9 & -27.4 & -28.6 & 3 & 2.0 & -0.42 & 3.7 & 1.6 & 3 & 2.1 \\
\hline Polynoid & -16.2 & -15.4 & -15.8 & 2 & & 8.8 & 10.5 & 9.7 & 2 & \\
\hline Pycnogonoid & & & -27.5 & 1 & & & & 6.5 & 1 & \\
\hline
\end{tabular}

fauna analysed, these animals had $\delta^{15} \mathrm{~N}$ values above $11 \%$ and and $\delta^{13} \mathrm{C}$ values near $-19 \%$. The 'near field' animals were collected from areas without direct exposure to detectable vent effluent and are either species endemic to vents or were collected from areas colonized by vent endemics. Several of the extreme $\delta^{15} \mathrm{~N}$ and $\delta^{13} \mathrm{C}$ values found in the vent fauna were from this subset of animals. The 'central' fauna were collected from among either Riftia pachyptila, Bathymodiolus thermophilus or Calyptogena magnifica. The $\delta^{13} \mathrm{C}$ values in these animals ranged from -34 to $-12 \%$ (overlapping the nonvent fauna) and the $\delta^{15} \mathrm{~N}$ values from -5 to $10 \%$ (lower than the non-vent fauna).

In Fig. $1 \mathrm{~b}$ the ranges of $\delta^{13} \mathrm{C}$ and $\delta^{15} \mathrm{~N}$ measured in the tissues of the dominant symbiont-containing invertebrates (Table 2) were used to delineate the ranges in these parameters indicated by the solid boxes. The dotted lines added on to the boxes encompass the additional range necessary to include the non-gill tissues of the bivalves collected (Fisher et al. 1988a, b) and the additional range in $\delta^{13} \mathrm{C}$ to be expected in juvenile Riftia pachyptila as indicated by analysis of a size series of $R$. pachyptila from $13^{\circ} \mathrm{N}$ on the East Pacific Rise (Fisher et al. 1990). The box labeled 'nonvent' encompasses the range of values found in this study and values reported for other ambient deep-sea fauna by Van Dover \& Fry (1989).

The $\delta^{13} \mathrm{C}$ and $\delta^{15} \mathrm{~N}$ values were determined for 9 paired samples of commensal polynoids and their host mussel (Fig. 2a, b). Commensal $\delta^{13} \mathrm{C}$ values were always between 2.5 and 4 units higher ( $\mathrm{avg} .=3.25 \%$, SD $=0.6$ ) than their host mussel and between 0.9 and 5.5 units greater (avg. $=3.2 \%, \mathrm{SD}=1.7$ ) than their host $\delta^{15} \mathrm{~N}$ value. The large range in $\delta^{15} \mathrm{~N}$ values in the mussels 


Non-vent
A Lo. pycogonid
Central
$\diamond$ B. symmythurian
$\Delta$ Phymorrhynchus sp.
a L. postulosis
$\nabla$ E. vitrea
$\circ$ N. fretterae
$\times$ A. lusca
$\triangle$ B. thermydron

Near Fleld

O Jellyfish

$\triangle$ Anemone

Serpulid
- M. squamosa

$\varnothing$ V. sulfuris

+ B. hollisi

- Polynoid

A Sm. pycnogonid

- E. rosacea

Fig. 1 (a) $\delta{ }^{13} \mathrm{C}$ vs $\delta^{15} \mathrm{~N}$ values for non-symbiontcontaining fauna from 3 Galapagos vent fields. Non-vent: fauna collected from outside of the vent field (but within $100 \mathrm{~m}$ of active flow); near field: fauna collected from within the vent field but not in association with symbiont-containing fauna or detectable vent effluent; central: fauna collected from among either Bathymodiolus thermophilus, Calyptogena magnifica or Riftia pachyptila. See Table 3 for common names. (b) The solid rectangles represent the measured ranges of $\delta^{13} \mathrm{C}$ and $\delta^{15} \mathrm{~N}$ values for $R$. pachyptila (Rp), C. magnifica $(\mathrm{Cm})$, B. thermophilus (Bt) and non-vent fauna, and are superimposed on the $\delta^{13} \mathrm{C}$ vs $\delta^{15} \mathrm{~N}$ values for fauna collected among the tubeworms and bivalves. Areas enclosed by the dotted lines are the additional ranges of $\delta^{13} \mathrm{C}$ and $\delta^{15} \mathrm{~N}$ values expected in other tissues and individuals of each species, based on previous work (see text)

analyzed was reflected in a correlated large range in the commensals $(\mathrm{p}=0.0004$ for the regression line, Fig. 2b).

There was no evidence of chemoautotrophic symbionts in any of the 3 species examined by enzyme analysis or TEM. RuBP carboxylase activity was not detected in the gills of the molluscs (Phymorrhynchus sp. and Neomphalus fretterae) nor in either gut or whole body extracts of the commensal polychaete Branchipolynoe symmytilida (data not shown). Sections from 3 areas in pieces of gill from each of 2 molluscs were examined by TEM and no evidence of bacterial symbionts were visible in any specimen examined. Mitochondria were readily visible in all sections examined indicating that the tissue preparation was of sufficiently good quality to visualize symbionts had they been present in the samples.
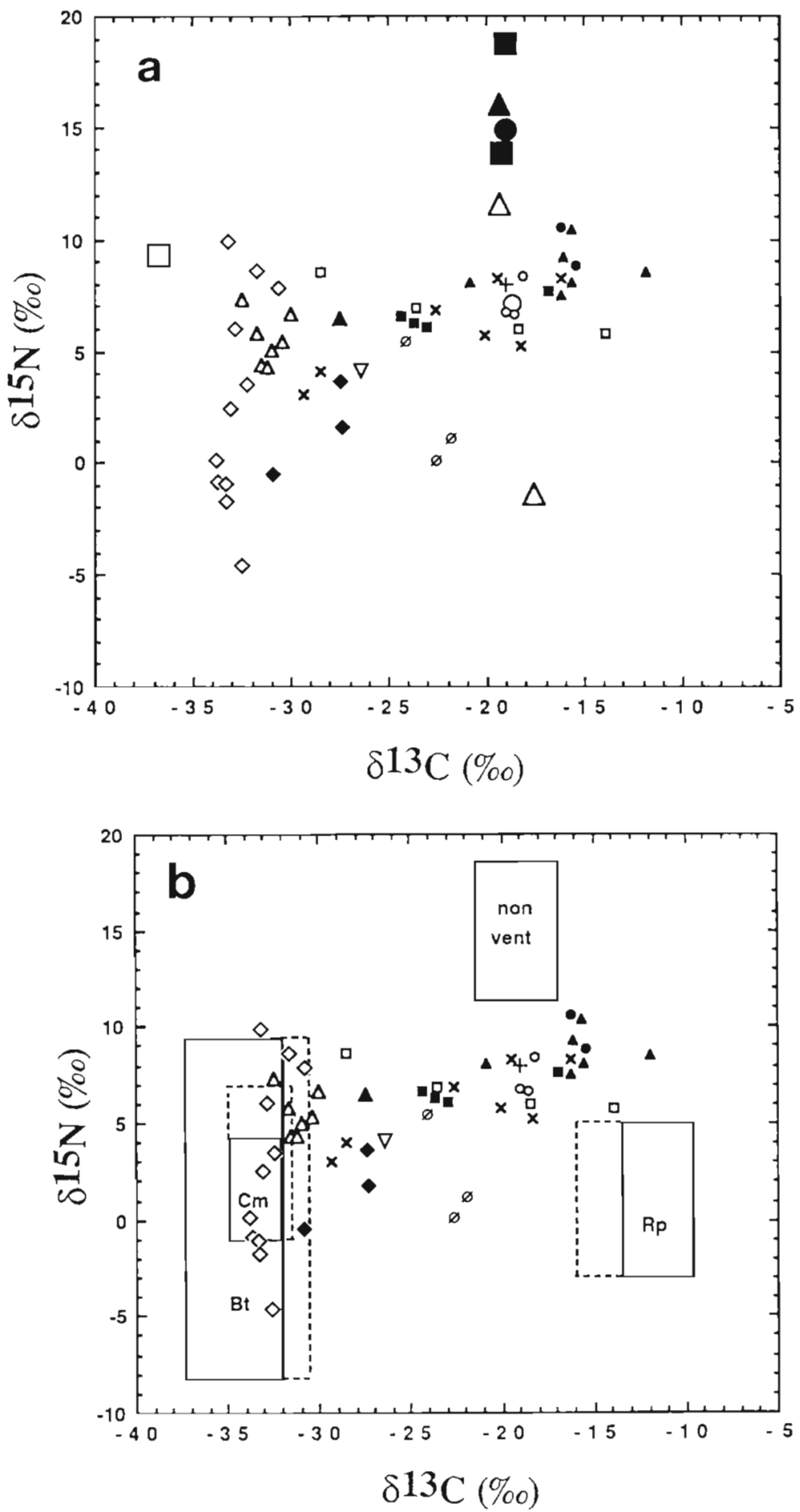

\section{DISCUSSION}

Owing to their remoteness and the relatively crude nature of the sampling tools available, hydrothermal vent community ecology is inherently difficult to study. Clearly, studies and analyses which can be conducted 

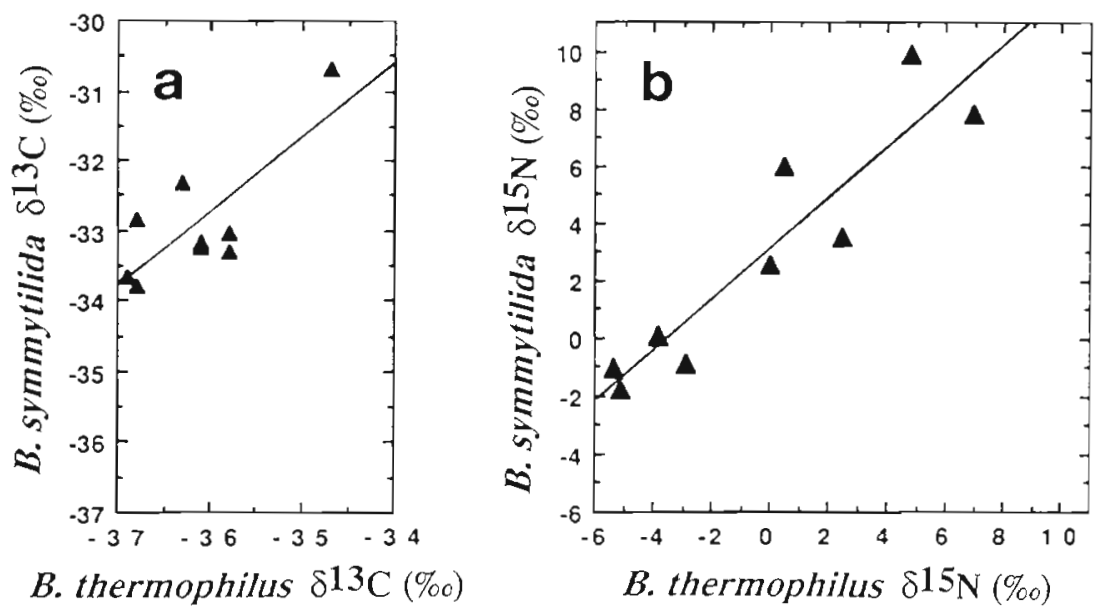

Fig. 2. (a) Relation between the $\delta^{13} \mathrm{C}$ values of individual hydrothermal vent mussels, Bathymodiolus thermophilus, and their commensal polychaetes, Branchipolynoe symmytilida. Equation of the line shown is $y=$ $1.065 x+5.62, n=9, p=0.013,95 \%$ confidence interval for the slope $=$ \pm 0.758 . (b) Relation between the $\delta^{15} \mathrm{~N}$ values of individual hydrothermal vent mussels, $B$, thermophilus, and their commensal polychaetes, B. symmytilida. Equation of the line shown is $y=0.884 x+3.16$, $\mathrm{n}=9, \mathrm{p}=0.0004,95 \%$ confidence interval for the slope $= \pm 0.325$ on frozen or preserved samples are potentially very useful for the study of these remote communities (Childress \& Fisher 1992). Stable isotope analysis provided the first data that the vent animals derived their nutritional carbon and nitrogen from local (vent) sources (Rau \& Hedges 1979, Rau 1981a, b). Many subsequent studies have used stable isotope data as evidence of symbiosis with either chemoautotrophic or methanotrophic bacteria (see Fisher 1990 for review). The results of this study and previous work (Van Dover \& Fry 1989, Kennicutt et al. 1992, Van Dover \& Fry 1993) support the usefulness of stable isotopes as indicators of reliance of other vent fauna on endogenous $\mathrm{C}$ and $\mathrm{N}$ sources.

The $\delta^{13} \mathrm{C}$ values of endemic vent species vary over a wide range, from $-37 \%$ to $-9 \%$, and much of the fauna is within the range reported for non-vent deepsea fauna $(-17$ to $-22 \%$ ) (Brooks et al. 1987, Van Dover \& Fry 1989). It is only at the ends of the distribution (below about $-25 \%$ and above about $-14 \%$ ) that one can draw conclusions concerning the endemic origin of the carbon source. However, $\delta^{13} \mathrm{C}$ values between -17 and $-22 \%$ do not rule out endemic $\mathrm{C}$ sources for the vent fauna, as values in this range could be due to either a free-living bacterial source with $\delta^{13} \mathrm{C}$ values in this range or a mixed diet of bacteria and/or metazoans with $\delta^{13} \mathrm{C}$ values on both sides of this range. In fact, the $\delta^{15} \mathrm{~N}$ values, as well as numerous in situ observations, indicate most of the vent consumers are deriving their nutrition primarily from vent sources.

On the other hand, $\delta^{15} \mathrm{~N}$ values of vent and non-vent fauna fall into 2 generally discrete groups: those with values above $11 \%$ and those with compositions below $11 \%$. When further information is available on the feeding biology of the animal in question, this demarcation is even more clear, in that carnivores will be expected to be further removed from the $\delta^{15} \mathrm{~N}$ of the original autotrophic source than would grazers or filter or deposit feeders with close trophic links to the source (about 3 to $3.4 \%$ per trophic level; Minagawa \& Wada 1984, Macko et al. 1987). Thus, with the exception of higher level carnivores, animals with $\delta^{13} \mathrm{C}$ values in the range of ambient deep-sea fauna $(-17$ to $-22 \%$ ) and $\delta^{15} \mathrm{~N}$ above about $10 \%$ are likely obtaining their nutrition $\mathrm{C}$ and $\mathrm{N}$ from non-vent sources. On this basis, the large pycnogonid, the holothurians, and some of the anemones are deriving at least the bulk of their nutrition from non-vent deep-sea sources. The number of individuals analyzed of each of these species is too low for these results to be generalized beyond the individuals analyzed; however, these data are in concurrence with their distribution in, and collection from outside of, the vent field.

One major conclusion which can be reached from this data set is that there is considerable variation in the stable isotope content of many vent species, even in the primary producers. Considerable information is lost when only 1 or 2 individuals of a given species are analyzed or specimens pooled before analysis. For example, considerable variation in both $\delta^{13} \mathrm{C}$ and $\delta^{15} \mathrm{~N}$ values were found in the shrimp Alvinocaris lusca. These data indicate that this mobile grazer/scavenger obtains nutritional $\mathrm{C}$ and $\mathrm{N}$ from a variety of sources, either at several levels on the food chain, or as suggested by the $13 \%$ variation in $\delta^{13} \mathrm{C}$, from at least 2 primary producer pools. In some of the other consumers, such as the gastropod Phymorrhynchus sp. and the limpet Neomphalus fretterae, a much tighter coupling to a single food source is indicated by their stable isotope content. Therefore, one should not draw conclusions concerning the trophic level or food sources for any species from data on pooled specimens or from data on very few individuals unless the food sources and species in question are known to have uniform stable isotopic contents (cf. Van Dover \& Fry 1989). 
$\diamond$ B. symmytilida

$\Delta$ Phymorrhynchus sp.

- L. postulosis

$\nabla$ E. vitrea

- N. fretterae

$\times$ A. lusca

- B. thermydron
- M. squamosa

$\checkmark$ V. sulfuris

+ B. hollisi

- Polynoid

- Sm. pycnogonid

- E. rosacea

Fig. 3. (a) Ranges of $\delta^{13} \mathrm{C}$ and $\delta^{15} \mathrm{~N}$ values for individual symbiont-containing species and ranges predicted for consumers of those species individually, assuming $\mathrm{a}+1 \%$ o shift in $\delta^{13} \mathrm{C}$ and $\mathrm{a}+3.5 \%$ shift in $\delta^{15} \mathrm{~N}$, superimposed on the $\delta^{13} \mathrm{C}$ vs $\delta^{15} \mathrm{~N}$ values for fauna collected among the tubeworms and bivalves. (b) Ranges of $\delta^{13} \mathrm{C}$ and $\delta^{15} \mathrm{~N}$ values for primary producers, and estimated ranges for primary and secondary consumers feeding on a mixture of vent primary producers, assuming a $+1 \%$ shift in $\delta^{13} \mathrm{C}$ and $\mathrm{a}+3.5 \%$ shift in $\delta^{15} \mathrm{~N}$ for each trophic level (see text for additional details)

A second consideration is the validity of calculating the number of trophic levels within a community directly from the range of $\delta^{15} \mathrm{~N}$ values found in the fauna (Van Dover \& Fry 1989). There is considerable variation in the $\delta^{15} \mathrm{~N}$ values of primary producers. This is likely due to a combination of differential utilization of the various nitrogen sources available to the primary producers (nitrate, ammonium, and molecular nitrogen), variation in the $\delta^{15} \mathrm{~N}$ values and concentrations of those sources in hydrothermal vent effluent (Lilley et al. 1993) and the variety of primary producers present. One example of this is the range of $\delta^{15} \mathrm{~N}$ values in Bathymodiolus thermophilus of over $17 \%$ (there are other examples as well). Although this mussel can filter feed, it is certainly feeding primarily on suspended vent bacteria (Page et al. 1991) and thus the range in $\delta^{15} \mathrm{~N}$ values is still a reflection of a large range in $\delta^{15} \mathrm{~N}$ at the base of the food chain. In light of these ranges and lack of consistent values in the primary producers, one cannot simply determine the number of trophic levels in a vent community by dividing the range of $\delta^{15} \mathrm{~N}$ values by a trophic level shift (3.0 to 3.5\%; Minagawa \& Wada 1984, Macko et al. 1987).

A third general conclusion one can reach from these data has been reached by previous researchers (Van Dover \& Fry 1989), namely that many of the consumers are feeding on a carbon and nitrogen source other than the symbiotic species, presumably free-living bacteria. Van Dover \& Fry (1989) found that many of the con-
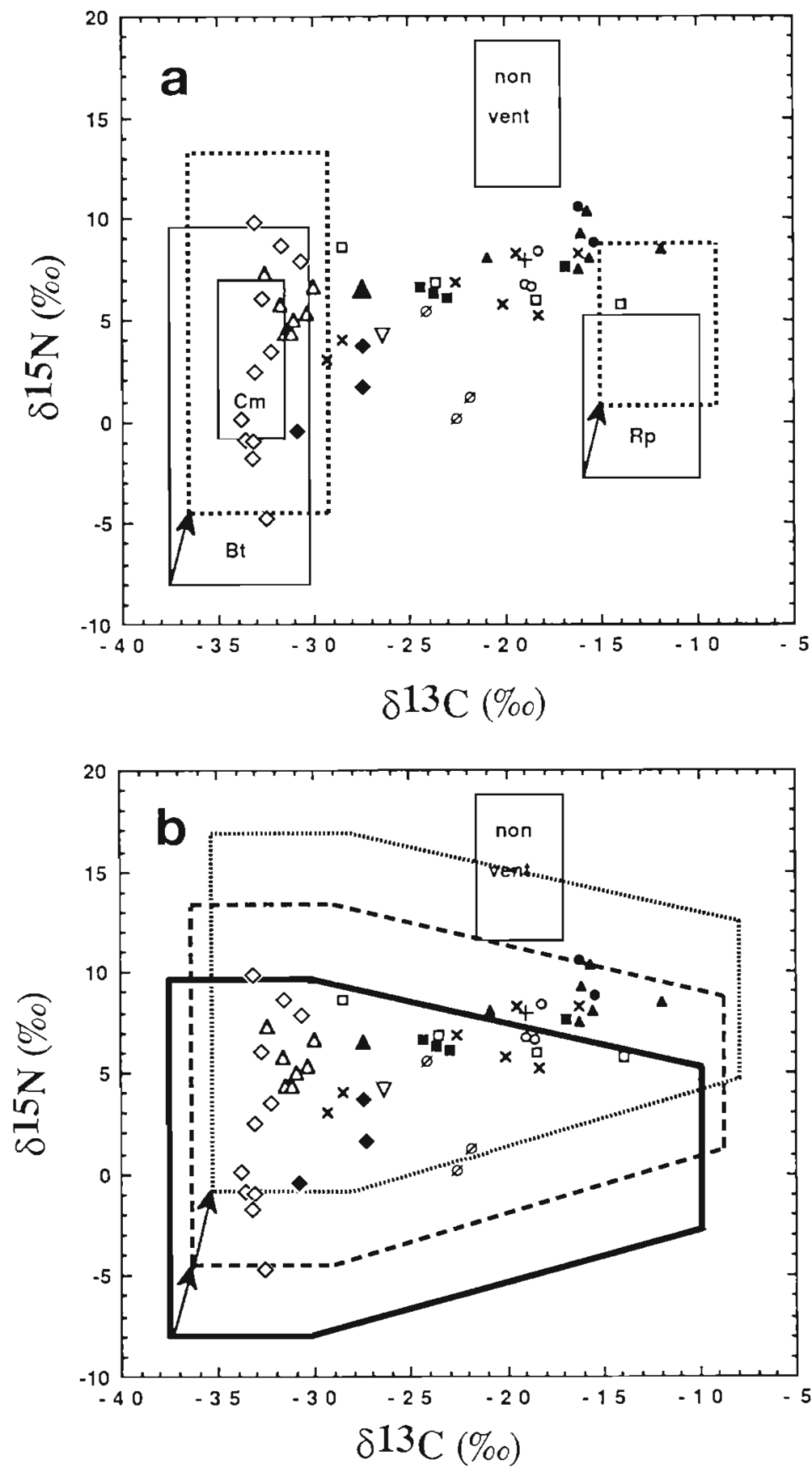

sumers from the Marinas vents had $\delta^{13} \mathrm{C}$ values in the -12 to $-16 \%$ range, although no tubeworms are present at these sites. They argue convincingly that there is a source of free-living bacteria with $\delta^{13} \mathrm{C}$ values in that range at that site, even though laboratory studies would suggest much lower values for free-living chemoautotrophic bacteria (Ruby et al. 1987). Based on the wide range of values found in grazers including limpets (Lepetodrilus pustulosis and Euleptopsis vitrea), shrimp (Alvinocaris lusca) and amphipods (Ventiella sulfuris) at the Galapagos sites, it is suggested 
that there is a wide range in the $\delta^{13} \mathrm{C}$ and $\delta^{15} \mathrm{~N}$ values in the free-living bacterial populations found in different microhabitats throughout the Galapagos vent fields.

In Fig. 3a the solid boxes encompass the same range of values found in the 3 dominant symbiont-containing species delineated by the solid and dotted lines in Fig. 1b. The dotted boxes encompass the range of values to be expected in a consumer of those species, assuming a $3 \%$ shift in nitrogen and a $1 \%$ shift in carbon (Minagawa \& Wada 1984, Macko et al. 1987). The only groups of consumers with stable isotope values directly linking them to symbiont-containing fauna were Phymorrhynchus sp. (a large white turrid gastropod) and Branchipolynoe symmytilida (a polynoid commensal in the mussels), which both showed strong trophic links to the bivalves, and most likely the mussels. The 3 individuals of the free-living polychaete Euphrosine rosecea had tissue $\delta^{13} \mathrm{C}$ values in the same range and somewhat more negative $\delta^{15} \mathrm{~N}$ values. Little is known concerning the feeding biology of this species, but these values suggest nutritional links with the mussels.

Phymorrhynchus sp. (Warén \& Bouchet 1989) was abundant at the Galapagos vents in 1988. It was not seen in central areas with high levels of venting, but rather was relegated to the peripheral mussel beds and even more peripheral areas, as was reported for Rose Garden in 1985 (Hessler et al. 1988). Warén \& Bouchet (1989) report on the remains (a radula) of Neomphalus fretterae in the stomach of 1 individual from $13^{\circ} \mathrm{N}$; however, the distribution of the 2 species at the Galapagos vents, as well as their $\delta^{13} \mathrm{C}$ values reported here, make that an unlikely food source for the gastropod. This gastropod has been observed feeding on the gills of a mussel damaged during collection and the stable isotope ratios of both these strongly suggest that this is a natural food source for this gastropod. Of all freeliving species assayed, the stable isotope content of this gastropod is most tightly linked to the bivalves, the mussels from peripheral vent sites in particular (Fisher et al. 1988a). Whether this is a reflection of feeding on clams or mussels which have been damaged by crabs, or feeding directly on adults, juveniles, mucous or pseudofeces produced by the bivalves, cannot be distinguished. The possibility that the $\delta^{13} \mathrm{C}$ and $\delta^{15} \mathrm{~N}$ values of the gastropod could be due to symbiotic bacteria was tested by assaying the gills for RuBP carboxylase activity (indicative of chemoautotrophy; Fisher 1990) and by examining several gill sections for the presence of intracellular symbiotic bacteria. No such evidence of endosymbionts in this species was found.

Commensal polychaetes have been found in about one-third of the mussels (Bathymodiolus thermophilus) collected from the Galapagos vents, with the fre- quency of occurrence varying dramatically with the collection site (Fisher et al. 1988a). The consistent relation between mussel and commensal $\delta^{13} \mathrm{C}$ values (the commensals are between 2.5 and $4 \%$ heavier than their host; Fig. 2a) and the significant correlation between mussel and commensal $\delta^{15} \mathrm{~N}$ values over a large range of $\delta^{15} \mathrm{~N}$ values (Fig. 2b) indicate a strong nutritional link between these species. Both the average difference between host and commensal $\delta^{15} \mathrm{~N}$ values $(3.2 \%)$ and the intercept of the regression line $(3.16 \%)$ support the expected trophic enrichment in $\delta^{15} \mathrm{~N}$ of between 3.0 and $3.4 \%$ (Minagawa \& Wada 1984, Macko et al. 1987, Harrigan et al. 1989). However, the difference between host and commensal $\delta^{13} \mathrm{C}$ values $(3.25 \%)$ and the intercept of the regression line $(5.6 \%)$ are greater than the predicted trophic enrichment for $\delta^{13} \mathrm{C}$ (1\%; Minagawa \& Wada 1984). Since obvious damage to mussel soft parts was only infrequently observed during dissection of hundreds of animals, it is concluded that the commensals are obtaining significant input of nutritional $\mathrm{C}$ and $\mathrm{N}$ from either mucous, feces or other matter released by the mussels. Utilization of a specific mussel by-product, rather than tissues, by the commensals could explain the anomalous trophic enrichment in $\delta^{13} \mathrm{C}$. RuBP carboxylase assays conducted on both internal tissues and whole (ground) animals were also negative for this species, and it is thus unlikely that the isotopic content of this polychaete is due to its own symbionts.

Although adult Riftia pachyptila are abundant at Rose Garden, and certainly constitute a significant portion of the biomass and primary production, there is no strong isotopic evidence that any of the species analyzed derive all of their nutrition from adult $R$. pachyptila (Fig. 3a). Some individual limpets and some bythogreid crabs may be deriving the major portion of their carbon and nitrogen from $R$. pachyptila or their tubes [vestimentiferan tube $\delta^{13} \mathrm{C}$ values reflect the $\delta^{13} \mathrm{C}$ values of that individual's soft tissues within $5 \%$ (Fisher et al. 1990)]; however, as populations, these species are only loosely linked to this carbon source. Both vestimentiferan gametes (due to high lipid levels) and juveniles (see Fisher et al. 1990) are likely to have different stable isotope composition from the adults, and these are potential vehicles for transfer of vestimentiferan $\mathrm{C}$ and $\mathrm{N}$ to the surrounding fauna.

In Fig. $3 \mathrm{~b}$ a polygon including the range of $\delta^{13} \mathrm{C}$ and $\delta^{15} \mathrm{~N}$ values of all the symbiont-containing invertebrates and all intermediate values is superimposed on the plot of the presumed heterotrophic vent species. This polygon includes the extreme $\delta^{15} \mathrm{~N}$ and $\delta^{13} \mathrm{C}$ values found in the symbiont-containing species and all intermediate values. Even more depleted $\delta^{13} \mathrm{C}$ and $\delta^{15} \mathrm{~N}$ values have recently been reported for bacterial mats from other vent sites (Van Dover \& Fry 1993). The 
dashed polygon represents the above subset with a single trophic level shift and the dotted line 2 trophic level shifts. These polygons are not intended to be exclusionary subsets of the data but rather a visual aid to separating species which are clearly higher level consumers (i.e. brachyuran crabs), from consumers at the base of the food chain (i.e. polychaetes), and also indicates consumers which bridge several trophic levels (i.e. shrimp).

The bythogreid crab Bythograea thermydron has been observed feeding on Riftia pachyptila plumes, as well as a variety of damaged (by the submersible) vent fauna. The carnivorous habit is typical for this group of crabs. Their stable isotopic carbon and nitrogen content is consistent with the behavioral observations of feeding on $R$. pachyptila, although the $\delta^{13} \mathrm{C}$ values indicate that in most cases this is not their sole $C$ source [although much of this range could be accounted for by significant feeding on juvenile vestimentiferans (Fisher et al. 1990)\}. The relatively heavy $\delta^{15} \mathrm{~N}$ values found in the 7 individuals analyzed are consistent with both in situ observations, and their morphology, which suggest they are a top predator endemic to these vents.

Munidopsis squamosa, the galatheid crab, is widespread throughout the vent field, to the periphery and beyond, but is virtually absent from central areas of active venting (such as among tubeworms). It does not usually come to baited traps (unlike Bythograea thermydron) nor is it quickly attracted to fauna damaged by the submersible (as is $B$. thermydron). Its anatomy and the fact that no individuals had tissue $\delta^{15} \mathrm{~N}$ values below 6.3 suggest it is a mid-level consumer, but the small sample size and the large range in $\delta^{15} \mathrm{~N}$ values inferred among primary producers make this uncertain, as does the behavior described above. The adults and juveniles ( $<1 \mathrm{~cm}$ carapace length) analyzed had different ranges of tissue $\delta^{13} \mathrm{C}$ values. Although the sample sizes are too small for definitive conclusions, this suggests the possibility of differential resource utilization by adults and juveniles.

The limpet Lepetodrilus pustulosis is widely distributed in the vent fields and occurs on rocks, tubeworm tubes and mussels at the Galapagos vents (R. R. Hessler \& W. M. Smithey pers. obs.). The range in $\delta^{13} \mathrm{C}$ values found in the 6 individuals analyzed $(-13.9$ to $-28.5 \%$ o) is wider than the range found in any other species and indicates that individuals in this species utilize a carbon source with a wide range of $\delta^{13} \mathrm{C}$ values. The range in $\delta^{15} \mathrm{~N}$ values is less than $3 \%$ and suggests a $\mathrm{N}$ source in the 2.5 to $5 \%$ range. Morphological observations suggest that this species is a deposit feeder (grazer) and its distribution at Galapagos vents suggests that the species 'wander during their regular activities' (Hessler \& Smithey 1983).
The shrimp Alvinocaris lusca also had a wide range of tissue $\delta^{13} \mathrm{C}$ values (from -16.3 to $-29.3 \%$ ) with an apparent bimodal distribution ( 3 individuals between -27.8 and $-29.3 \%$ and 7 individuals between -16.2 and $-22.6 \%$ ). Like the limpets, the range in tissue $\delta^{15} \mathrm{~N}$ is much smaller and suggests a source in the -0.5 to $5 \%$ range. Also like the limpet, it is found associated with both mussels and tubeworms, often at areas of active venting. Morphological observations suggest that this shrimp is also a deposit feeder, grazing surfaces with its chelipeds. Amphipods (e.g. Ventiella sulfuris) were occasionally found in the collection box after removal of the larger invertebrates. Like the grazers discussed above there was a significant range in the tissue $\delta^{13} \mathrm{C}$ values among individuals and a smaller range in tissue $\delta^{15} \mathrm{~N}$, indicating a food source in the -3.3 to $2 \%$ range. Thus, the organisms on which these animals are feeding have $\delta^{13} \mathrm{C}$ values which extend over a range which encompasses almost the entire range of values found among hydrothermal vent invertebrates, indicating free-living primary producers with a similar range of $\delta^{13} \mathrm{C}$ values. The relatively low $\delta^{15} \mathrm{~N}$ values inferred in this attached biota also indicates that it is near the base of the food chain (primary producers and primary consumers).

The limpet Neomphalus fretterae (McLean, 1981) was collected from rocks which were covered by a mat of Bathymodiolus thermophilus and Riftia pachyptila. The limpets were not visible until after the mussels had been removed. In among the tubeworms was another species of tubeworm (Oasisia alvinae?) which has tissue $\delta^{13} \mathrm{C}$ values in the same range as other hydrothermal vent vestimentiferans (Fisher et al. 1990). The limpets formed an aggregation, similar to that described in Hessler \& Smithey (1983), of individuals densely packed together, with the shape of the shell margins conforming to adjacent individuals. Because of the limpet's habit and habitat, pieces of its gill tissue were assayed for RuBP carboxylase and examined by TEM. No activity of the enzyme was detected in the 2 individuals assayed and no bacteria were seen in the sections from the same individuals. Based on these data, the observations of very limited mobility, and the anatomical studies of McLean (1981), it appears that suspension feeding dominates in these clusters (Hessler \& Smithey 1983). A particulate source with a ${ }^{13} \mathrm{C}$ in the -16 to $-18 \%$ range and $\delta^{15} \mathrm{~N}$ in the 3 to $7 \%$ range is suggested (see Table 3 for the full range of $\delta^{13} \mathrm{C}$ and $\delta^{15} \mathrm{~N}$ values in $N$. fretterae).

For reasons ranging from rarity of the individuals to difficulties in collecting specimens, to irretrievably lost samples, only single individuals of several taxa were analyzed, and either $\mathrm{C}$ or $\mathrm{N}$ were analyzed for several samples. In these situations only very general conclusions are appropriate and even 
these should be considered preliminary until further data is available.

A single unidentified jellyfish was collected over Mussel Bed in 1988. Its stable carbon content is consistent with either a non-vent carbon source or a mixed diet of vent particles. Its tissue $\delta^{15} \mathrm{~N}$ is lighter than other ambient deep-sea fauna and suggests either input of vent organics or could be a reflection of the paucity of data on the range of $\delta^{15} \mathrm{~N}$ in non-vent deep-sea fauna. The hydrothermal vent fish Bythites hollisi has very similar tissue $\delta^{13} \mathrm{C}$ and $\delta^{15} \mathrm{~N}$ values to the jellyfish. However, this is an abundant, endemic vent species often seen immersed in vent flow and its tissue isotopic content is likely a reflection of its locally produced food source. The identity of the food source is uncertain; it has never been observed feeding, nor does it come to baited traps. A small pycnogonid found in the collection box after a mussel collection, a colonial siphonophore (Thermopalia taraxaca), a limpet (Euleptopsis vitrea) and a serpulid (sp. b) all have a clear chemoautotrophic carbon signal $\left(\delta^{13} \mathrm{C}<-25 \%\right)$, indicating the reliance of these individuals on chemoautotrophically produced organic carbon (Table 3 , Fig. 1a). The serpulid had the most negative tissue $\delta^{13} \mathrm{C}$ value of any of the fauna analyzed and one of the heaviest $\delta^{15} \mathrm{~N}$ values. This species deserves further study. Another outlier was one of the anemones (Isoparactis sp.) which had one of the most negative $\delta^{15} \mathrm{~N}$ values. This suggests it is feeding near the base of the food chain on locally produced organics and once again implies hydrothermal vent primary producers with relatively heavy $\delta^{13} \mathrm{C}$ values.

Stable carbon and nitrogen isotopes are proving to be valuable tools in the study of hydrothermal vent fauna and community structure. The clear signals produced by the vent primary producers in most cases allow easy identification of reliance on vent-produced organics, when both carbon and nitrogen are considered together. As more data is collected it is also becoming apparent that interpretation of $\delta^{13} \mathrm{C}$ and $\delta^{15} \mathrm{~N}$ values in hydrothermal vent fauna can be quite complex, due to the heterogeneity of the values in the primary producers and the putative substantial utilization of free-living bacteria as food.

Acknowledgements. We thank the captain and crew of the RV 'Melville' and the RV 'Atlantis II', and the 'Alvin' pilots and support crew, without whose expertise and assistance this work would not have been possible. We thank K. Johnson for obtaining the water samples with his 'Scanner', R. Hessler for sharing valuable insights and observations. $J$. Dugan and V. Vandevar for assistance at sea, and J. Vodenichar and J. Zande for technical laboratory assistance. This work was supported by NSF grants EAR-9158113 and OCE-9114386 to C.R.F., OCE-8610514 to J.J.C. and C.R.F., OCE-9012076 and OCE-9301374 to J.J.C., and grants from NSERC to S.A.M.

\section{LITERATURE CITED}

Brooks, J. M., Kennicutt, M. C. II, Fisher, C. R., Macko, S. A., Cole, K., Childress, J. J., Bidigare, R. R., Vetter, R. D. (1987). Deep-sea hydrocarbon seep communities: evidence for energy and nutritional carbon sources. Science 20: $1138-1142$

Calder, J. A., Parker, P. L. (1973). Geochemical implications of induced changes in ${ }^{13} \mathrm{C}$ fractionation by blue-green algae. Geochim Cosmochim. Acta 37. 133-140

Cavanaugh, C. M. (1985). Symbiosis of chemoautotrophic bacteria and marine invertebrates from hydrothermal vents and reducing sediments. Bull. Biol. Soc. Wash. 6: $373-388$

Childress, J. J., Fisher, C. R. (1992). The biology of hydrothermal vent animals: physiology, biochemistry and autotrophic symbiosis. Oceanogr. mar. Biol. A. Rev. 30: $337-441$

Childress, J. J., Lee, R. W., Sanders, N. K., Felbeck, H., Oros, D. R., Toulmond, A., Desbruyeres, D., Kennicutt, M. C. I., Brooks, J. (1993). Inorganic carbon uptake in hydrothermal vent tubeworms facilitated by high environmental $\mathrm{pCO}_{2}$. Nature 362: 147-149

Fisher, C. R. (1990). Chemoautotrophic and methanotrophic symbioses in marine invertebrates. Rev. aquat. Sci. 2: $399-436$

Fisher, C. R., Childress, J. J., Oremland, R. S., Bidigare, R. R. (1987). The importance of methane and thiosulphate in the metabolism of the symbionts of two deep-sea mussels. Mar. Biol. 96: 59-71

Fisher, C. R., Childress, J. J., Arp, A. J., Brooks, J. M., Distel, D., Favuzzi, J. A., Felbeck, H., Hessler, R., Jahnson, K. S., Kennicutt, M. C. II, Macko, S. A., Newton, A., Powell, M. A., Somero, G. N., Soto, T (1988a). Microhabitat variation in the hydrothermal vent mussel Bathymodiolus thermophilus, at Rose Garden vent on the Galapagos rift Deep Sea Res. 35: 1769-1792

Fisher, C. R., Childress, J. J., Arp, A. J., Brooks, J. M, Distel, D., Favuzzi, J. A., Felbeck, H., Fritz, L. W., Hessler, R., Johnson, K. S., Kennicutt, M. C. II, Lutz, R. A., Macko, S A., Newton, A., Powell, M. A., Somero, G. N., Soto, T (1988b). Microhabitat variation in the hydrothermal vent clam, Calyptogena magnifica, at Rose Garden vent on the Galapagos rift. Deep Sea Res. 35: 1811-1832

Fisher, C. R., Childress, J. J., Arp, A. J., Brooks, J. M., Distel D., Favuzzi, J. A., Macko, S. A., Newton, A., Powell, M. A. Somero, G. N., Soto, T. (1988c). Physiology, morphology, and composition of Riftia pachyptila at Rose Garden in 1985. Deep Sea Res. 35: 1745-1758

Fisher, C. R., Kennicutt, M. C. II, Brooks, J. M. (1990). Stable carbon isotopic evidence for carbon limitation in hydrothermal vent vestimentiferans. Science 247 $1094-1096$

Harrigan, P., Zieman, J. C., Macko, S. A. (1989). The base of nutritional support for the grey snapper (Latjanus griseus): an evaluation based on a combined stomach content and stable isotope analysis. Bull. mar. Sci. 44 $65-77$

Hessler, R. R., Smithey, W. M. Jr. (1983). The distribution and community structure of megafauna at the Galapagos Rift hydrothermal vents. In: Rona, P. A., Boström, K., Laubier, L. Smith, K. L. Jr. (eds.) Hydrothermal processes at seafloor spreading centers. Plenum Press, New York, p. $735-770$

Hessler, R. R., Smithey, W. M., Boudrias, M. A., Keller, C. H., Lutz, R. A., Childress, J. J. (1988). Temporal change in 
megafauna at the Rose Garden hydrothermal vent. Deep Sea Res. 35: 1681-1710

Hessler, R. R., Smithey, W. M., Keller, C. H. (1985). Spatial and temporal variation of giant clams, tubeworms and mussels at deep-sea hydrothermal vents. Bull. Biol. Soc. Wash. 6: $465-474$

Jannasch, H. W. (1983). Microbial processes at deep sea hydrothermal vents. In: Rona, P. A., Boström, K., Laubier, L., Smith, K. (eds.) Hydrothermal processes at sea floor spreading centers. Plenum Publishing Corp., New York, p. $677-709$

Jannasch, H. W. (1989). Chemosynthetically sustained ecosystems in the deep sea. In: Schlegel. H. G., Bowien, B. (eds.) Autotrophic bacteria. Science Tech, Madison, p. $147-166$

Kennicutt, M. C. Il, Burke, R. A. Jr, MacDonald, I. R., Brooks, J. M., Denoux, G. J., Macko, S. A. (1992). Stable isotope partitioning in seep and vent organisms: chemical and ecological significance. Chem. Geol. 101: 293-310

Lilley, M. D., Butterfield, D. A., Olson, E. J., Lupton, J. E., Macko, S. A., McDuff, R. E. (1993). Anamolous $\mathrm{CH}_{4}$ and $\mathrm{NH}_{4}{ }^{+}$concentrations at an unsedimented mid-ocean-ridge hydrothermal system. Nature $364: 45-47$

Macko, S. A., Fogel, M. L., Hare, P. E., Hoering, T C. (1987). Isotopic fractionation of nitrogen and carbon in the synthesis of amino acids by microorganisms. Chem. Geol (Isot. Geosci. Sect.) 65: 79-82

McLean, J. H. (1981). The Galapagos Rift limpet Neomphalus: relevance to understanding the evolution of a major Paleozoic-Mesozoic radiation. Malacologia 21: 291-336

Minagawa, M., Wada, E. (1984). Stepwise enrichment of ${ }^{15} \mathrm{~N}$ along food chains: further evidence and the relation between ${ }^{15} \mathrm{~N}$ and animal age. Geochim. Cosmochim. Acta 48: $1135-1140$

Owens, N. J. P. (1987). Natural variations in ${ }^{15} \mathrm{~N}$ in the marine environment. Adv. mar. Biol. 24: 389-451

Page, H. M., Fiala-Médioni, A., Fisher, C. R., Childress, J. J. (1991). Experimental evidence for filter-feeding by the hydrothermal vent mussel, Bathymodiolus thermophilus. Deep Sea Res. 38: 1455-1461

Rau, G. (1981a). Low ${ }^{15} \mathrm{~N} /{ }^{14} \mathrm{~N}$ in hydrothermal vent animals: ecological implications. Nature 289: 484-485

This article was submitted to the editor
Rau, G. H. (1981b). Hydrothermal vent clam and tubeworm ${ }^{13} \mathrm{C} /{ }^{12} \mathrm{C}$. Further evidence of nonphotosynthetic food sources. Science 213: $338-340$

Rau, G. H. $(1985) \cdot{ }^{13} \mathrm{C} /{ }^{12} \mathrm{C}$ and ${ }^{17} \mathrm{~N} /{ }^{14} \mathrm{~N}$ in hydrothermal vent organisms: ecological and biogeochemical implications. Bull. Biol. Soc. Wash. 6: 243-248

Rau, G. H., Hedges, J. I. (1979). Carbon-13 depletion in a hydrothermal vent mussel: suggestion of a chemosynthetic food source. Science 203: 648-649

Rau, G. H., Sweeney, R. E., Kaplan, I. R. (1982). Plankton ${ }^{13} \mathrm{C}:{ }^{12} \mathrm{C}$ ratio changes with latitude: differences between northern and southern oceans. Deep Sea Res. 29: $1035-1039$

Ruby, E. G., Jannasch, H. W., Deuser, W. G. (1987). Fractionation of stable carbon isotopes during chemoautotrophic growth of sulfur-oxidizing bacteria. Appl. environ. Microbiol. 53: 1940-1943

Sackett, W. M., Nakaparksin, S., Dalrymple, D. (1970). Carbon isotope effects in methane production by thermal cracking. In: Hobson, G. D., Speers, G. C. (eds.) Advances in organic geochemistry. Pergamon Press, Oxford, p. $37-53$

Schiklowski, M, Matzigkeit, U., Krumbein, W. E. (1984). Superheavy organic carbon from hypersaline microbial mats. Naturwissenschaften 71: 303-308

Schoell, M., Farber, E., Coleman, M. L. (1983). Carbon and hydrogen isotope comparisons of the NBS-22 and NBS-21 stable isotope reference materials: an inter-laboratory comparison. Org. Geochem. 5: 3-6

Van Dover, C. L., Fry, B. (1989). Stable isotopic compositions of hydrothermal vent organisms. Mar Biol. 102: 257-263

Van Dover, C. L., Fry, B. (1993). Evidence for site-specific heterogeneity of food resources at deep-sea hydrothermal vents. Limnol. Ocean. (in press)

Van Dover, C. L., Fry, B., Grassle, J. F., Humphris, S., Rona, P. (1988). Feeding biology of the shrimp Rimicaris exoculata at hydrothermal vents on the Midatlantic Ridge. Mar. Biol. 98: $209-216$

Warén, A., Bouchet, P. (1989). New gastropods from East Pacific hydrothermal vents. Zool. Scripta 18: 67-102

Wishnick, M., Lane, M. D. (1971). Ribulose diphosphate carboxylase from spinach leaves. Meth. Enzym. 23: 570-577

Manuscript first received: June 28, 1993

Revised version accepted: October 14, 1993 